\title{
Обґрунтування технічних вимог до прицілів протитанкових артилерійських гармат
}

\author{
Олексій Лазня ${ }^{1}$ А; Микола Дорофєєв ${ }^{2}$ в; Борис Мельник ${ }^{3 \text { в }}$ \\ А Науково-дослідний центр ракетних військ і артилерії, м. Суми, Україна \\ в Центральний науково-дослідний інститут озброєння та військової техніки ЗС України, м. Київ, Україна
}

Received: May 10, 2021 | Revised: June 10, 2021 | Accepted: June 30, 2021

DOI: $10.33445 /$ sds.2021.11.3.13

\begin{abstract}
Анотація
Розглянуто питання щодо формування технічних вимог до модернізованих прицілів протитанкових артилерійських гармат, запропоновано варіанти їх приладового оснащення і вимоги до нього.
\end{abstract}

Ключові слова: протитанкова артилерійська гармата, модернізований приціл, додаткове обладнання.

\section{Постановка проблеми}

Ефективність застосування протитанкових засобів при веденні бойових дій залежить від їх характеристик, серед яких - можливість розпізнавання й ураження цілей у будь-яку пору року та час доби.

100-мм протитанкова гармата МТ-12 обладнана оптичним прицілом, який не в повній мірі забезпечує наведення ії на ціль в умовах обмеженої видимості, а нічний приціл
АПН-6-40 $€$ конструктивно застарілим та малоефективним [1]. Це змушує вести активний пошук шляхів вирішення проблеми бойового застосування даного типу зразка ОВT, одним з яких $\epsilon$ модернізація протитанкового артилерійського прицілу, що замінить існуючі і, в цілому, підвищить бойову ефективність протитанкової гармати.

\section{Аналіз останніх досліджень та публікацій}

Аналіз аналогічного за типом озброєння найбільш розвинутих у військовому відношенні країн свідчить, що шлях модернізації значної частини озброєння та військової техніки $€$ перспективним, крім того, фінансові витрати на розвиток зразка OBT (модернізацію) можуть бути зменшені у декілька разів у порівнянні зі створенням нового зразка ОВТ. У багатьох країнах модернізація розглядається як один із основних шляхів технічного забезпечення обороноздатності збройних сил. Так, наприклад, США при прийнятті рішення про необхідність розроблення та виробництва нової системи зброї враховують можливості модернізації зброї, що знаходиться в експлуатації. Позитивне рішення приймається тільки в тому випадку, якщо всі можливості модернізації вичерпано або вона недоцільна [2].

\section{Постановка завдання}

Метою статті $€$ обґрунтування технічних вимог до прицілів протитанкових артилерійських гармат, доцільності напряму модернізації парку 100-мм протитанкових гармат МТ-12 3С України шляхом заміни застарілих прицілів ОП-4М-40У та АПН-6-40

\footnotetext{
1 *Corresponding author: начальник науково-дослідної лабораторії, e-mail: 1980yanzal@gmail.com, ORCID: 0000-0003-3667-2418

2 к.т.н., науковий співробітник науково-дослідного відділу, e-mail: dorofeev83@meta.ua, ORCID: 0000-0001-8607-2483

${ }^{3}$ к.т.н., начальник науково-дослідного відділу, е-mail: melnikboss1@gmail.com, ORCID: 0000-0002-5635-0099
} 
на універсальний приціл, що в повній мірі відповідатиме вимогам до ведення сучасних бойових дій та формування складу приладового

оснащення

для модернізації.

\section{Виклад основного матеріалу}

На даний час до складу 100-мм протитанкової гармати МТ-12 входить оптичний приціл ОП-4М-40У та артилерійський нічний приціл АПН-6-40.

Оптичний приціл ОП-4М-40У призначений для прицілювання під час стрільби прямою наводкою вдень.

Артилерійський нічний приціл АПН-6-40 призначений для спостереження за полемо бою та прицілювання при стрільбі прямою наводкою в темний час доби та в умовах пониження освітленості [3].

Досвід застосування протитанкових гармат МT-12 під час ведення активної фази антитерористичної операції (АТО) на сході України свідчить, що зазначені приціли не в повній мірі відповідають вимогам сьогодення і потребують глибокої модернізації. Враховуючи зазначене, модернізований приціл повинен забезпечувати виконання функцій штатного прицілу протитанкової гармати в умовах пониження освітленості видимого зображення об'єктів та місцевості, а також поєднувати функції далекоміра, тепловізора та балістичного калькулятора.

Далекомір - прилад для спостереження за полем бою, вимірювання кутів, дальності до нерухомих і рухомих цілей, місцевих предметів і розривів, а також для визначення магнітного азимута напрямків.

Далекоміри за принципом вимірювання поділяються на активні і пасивні. Принцип дії далекомірів активного типу полягає у вимірюванні часу, який витрачає посланий далекоміром сигнал для проходження відстані до об'єкта і назад. Принцип дії пасивних далекомірів оснований на тріангуляційному (параллаксному) методі.

Тепловізор - оптико-електронний прилад, призначений для візуалізації температурного поля та вимірювання температури. Тепловізор переважно працює в інфрачервоній частині електромагнітного спектру - теплові зображення утворюються завдяки зміщенню максимумів спектрів власного випромінювання тіл під час їх нагрівання у короткохвильову область [4]. Сучасні тепловізори забезпечують можливість спостереження та ідентифікації предметів за умов слабкого освітлення, повної темноти, задимленні, туману тощо [5].

Балістичний калькулятор - програмний комплекс спеціально розроблений для розрахунку поправок на відхилення від табличних умов стрільби під час стрільби з протитанкової гармати прямою наводкою та на велику відстань.

Зважаючи на зазначене, основним призначенням модернізованого прицілу повинно бути забезпечення наведення протитанкової гармати в ціль та спостереження за місцевістю (полем бою) у будь-який час доби та в умовах обмеженої видимості, визначення дальності до об'єкту (цілі) та визначення поправок на відхилення балістичних i метеорологічних умов стрільби від табличних.

Ураховуючи призначення модернізованого прицілу, його конструкція, комплектність і характеристики повинні забезпечувати прицілювання протитанкових гармат МТ-12 не гірше, ніж штатні приціли ОП-4М-40У та АПН-640, у тому числі, в умовах обмеженої видимості.

Отже, модернізований приціл повинен складатись:

з корпуса з механізмами прицілювання та упередження;

механізмів вивірки;

окуляра в оправі;

приладового оснащення;

гумового налобника.

Корпус призначений для кріплення в ньому основних складових і механізмів прицілу.

Механізми прицілювання та упередження призначені для встановлення необхідних кутів прицілювання та упередження відповідно.

Механізми вивірки прицілу по висоті та 
напрямку призначені для узгодження нульової лінії прицілювання з віссю каналу ствола.

Безпосередньо прицілювання гармати проводиться за допомогою декількох шкал і відповідних знаків, нанесених на плоскопаралельну пластинку, а саме:

дистанційних шкал;

шкали коректур за дальністю;

шкали бокової складової швидкості цілі;

шкали бокових поправок;

прицільних знаків;

далекомірної шкали;

кутників для визначення дальності прямого пострілу по цілях висотою 2,7 та 1,5 м.

Окуляр призначений для розглядання зображення, яке дає об'єктив, під великим кутом зору.

Далекомір, тепловізор та балістичний калькулятор $\epsilon$ приладовим оснащенням прицілу.

\section{Далекомір.}

Всі далекоміри можна розбити на дві групи:

активні далекоміри, що використовують у процесі вимірювання дальності підсвічування об'єкта за допомогою випромінювання лазера або світлодіода;

пасивні далекоміри, принцип дії яких оснований на тріангуляційному (паралаксному) методі. Далекоміри даної групи широко використовувалися в фототехніці “доцифрової" ери, але не забезпечували ні високої точності, ні великої дальності, тому, їх застосування у складі прицілу протитанкових гармат недоцільне.

у свою чергу, активні далекоміри за функціональною ознакою можна розбити на три типи:

лазерні фазові далекоміри - вимірюють дальність шляхом визначення зсуву фази гармонійного модульованого оптичного випромінювання лазера або світлодіода відносно опорного коливання;

інтерференційні лазерні далекоміри принцип дії заснований на підрахунку інтерференційних смуг при переміщенні реперного світлоповертального елемента від нульового положення до необхідного. Такі прилади мають обмежену область застосування внаслідок необхідності використання репера, а також малої вимірюваної дальності, хоча і мають дуже високу точність (більше 1 мкм). Далекоміри такого типу застосовують при високоточному технологічному контролі різних об'єктів;

лазерні імпульсні далекоміри - визначають дальність за часом поширення лазерного імпульсу до об'єкта і назад. Цей тип далекомірів забезпечує необхідні вимоги до точності визначення відстаней, відносно невелику вартість і габарити та $€$ найбільш доцільним вибором для включення в склад прицілу.

Тепловізор.

Принцип дії тепловізора полягає в наступному: інфрачервоне випромінювання цільового об'єкта фокусується на світлочутливій поверхні фокальної площини інфрачервоного детектора через інфрачервону оптичну систему. Після цього, інфрачервона фотоелектрична матриця детектора перетворює оптичний сигнал в електричний, який перетворюється контуром активної зони в цифровий відеосигнал шляхом дискретизації. Потім, цифровий відеосигнал обробляється алгоритмом зображення та інфрачервоне зображення видається на екран окуляра для допомоги користувачу в спостереженні та прицілювання на об'єкт. Принципова схема тепловізора показана на рис. 1 [6].

Для функціонування тепловізора передбачена наявність джерела живлення, а для забезпечення його безперервної роботи таких джерел повинно бути не менше двох. Для швидкого заряджання джерел живлення тепловізори комплектуються зарядним пристроєм.

Сучасні тепловізори мають можливість передачі зображення іншим користувачам як за допомогою USB кабелю, так і через Wi-Fi модуль. 


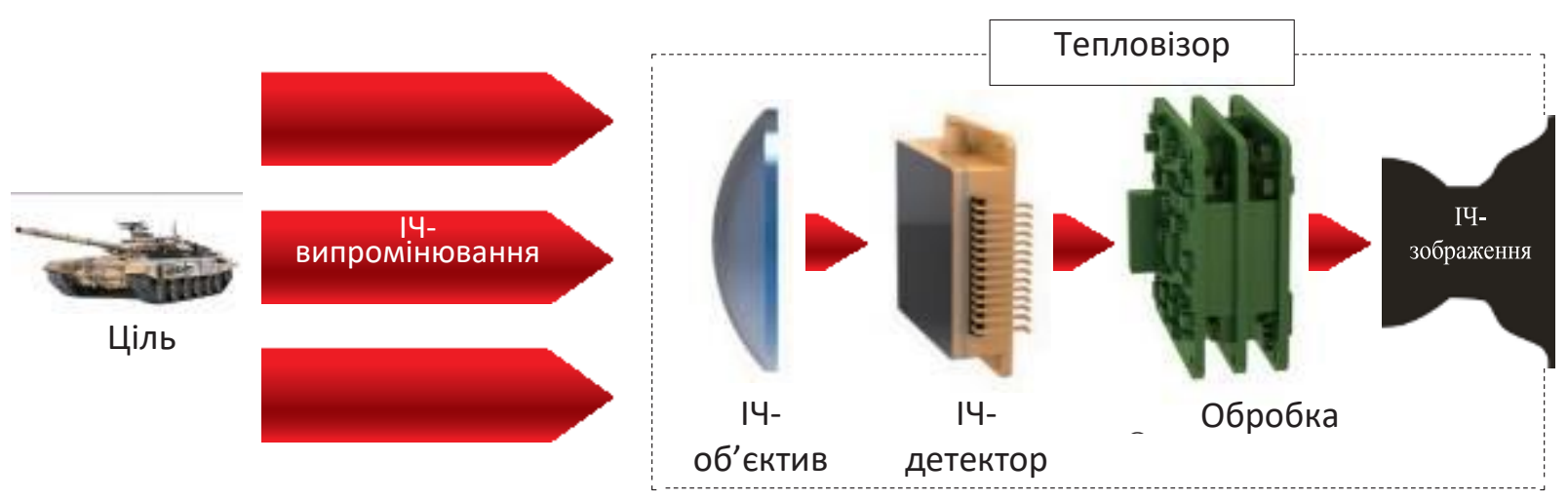

Рисунок 1 - Принципова схема тепловізора

Балістичний калькулятор.

Сучасні методи комп'ютерного моделювання дозволяють 3 великою точністю розрахувати балістичні процеси, що відбуваються під час руху артилерійського снаряда з урахуванням таких параметрів, як:

метеорологічні умови;

балістичні умови.

Врахувавши ці параметри програмний апарат балістичного калькулятора розрахує необхідні поправки в напрямок та приціл, що потрібні при стрільбі по цілях напівпрямою та прямою наводкою.

Таким чином, основними складовими модернізованого прицілу повинні бути:

корпус з пристосуваннями для закріплення на МТ-12 з роз'ємами;

оптико-електронна системами модулів далекоміра та тепловізора;

вбудований модуль 3 програмним комплексом для розрахунку поправок в напрямок та приціл, що потрібні при стрільбі по цілях напівпрямою та прямою наводкою;

блок живлення з акумуляторною батареєю (з можливістю швидкої заміни та зарядки);

механізм шкал (або можливість управління шкалами немеханічним способом); кнопки, перемикачі для управління приладом;

механізм (пристрій) вивірки по висоті та напрямку;

механізм (пристрій) для захисту від засвічування.

Завдання та можливості модернізованого прицілу будуть обумовлюватись призначенням і характеристиками оптичного прицілу протитанкової гармати, далекоміра, тепловізора та балістичного калькулятора.

Основними завданнями оптичного прицілу є забезпечення:

прицілювання гармати при стрільбі прямою наводкою бронебійним підкаліберним снарядом, кумулятивноосколковим і осколково-фугасним снарядом;

прицілювання гармати при стрільбі напівпрямою наводкою;

визначення бокових поправок для урахування швидкості руху цілі;

вимірювання дальності до цілі (дальності прямого пострілу) висотою 1,5 і 2,3 (2,7)м.

Загальні характеристики модернізованого прицілу мають бути не гірше штатного прицілу ОП-4М-40У, які наведено в таблиці 1. 


\section{Таблиця 1 - Основні характеристики оптичного прицілу ОП-4М-40У}

\begin{tabular}{|l|c|}
\hline \multicolumn{1}{|c|}{ Характеристика } & Значення \\
\hline Збільшення, крат. & 5,5 \\
\hline Поле зору, град & 11 \\
\hline Діаметр вихідного зрачка, мм & 5,5 \\
\hline Віддаль вихідного зрачка від останньої лінзи окуляра, мм & 24,5 \\
\hline $\begin{array}{l}\text { Допустима величина вивірки прицілу за напрямком та } \\
\text { висотою, поділ. кут. }\end{array}$ & $\pm 0-10$ \\
\hline Межі шкали бокових поправок, поділ. кут. & $\pm 0-22$ \\
\hline Межі шкали коректур за дальністю, поділ. кут. & від 0 до 0-70 \\
\hline Межі шкали швидкості, км/год & $0-80$ \\
\hline Вага прицілу, кг & 5 \\
\hline
\end{tabular}

Далекомір (модуль далекоміра) повинен рухомих та нерухомих об'єктів (цілей) 3 забезпечити вимірювання відстаней до характеристиками, наведеними в таблиці 2.

Таблиця 2 - Основні характеристики далекоміра

\begin{tabular}{|l|c|}
\hline \multicolumn{1}{|c|}{ Характеристика } & Значення \\
\hline Збільшення, крат. & не менше 7 \\
\hline Поле зору, град & не менше 11 \\
\hline Помилка вимірювання дальності, $M$ & не більше 5 \\
\hline Діапазон вимірювання відстаней, $M$ & від 100 та не менше 5000 \\
\hline Час готовності до вимірювання, с & не більше 5 \\
\hline
\end{tabular}

Тепловізор повинен забезпечити в умовах обмеженої видимості: виявлення, розпізнавання та ідентифікацію об'єктів (цілей) 3 характеристиками, наведеними в таблиці 3.

Таблиця 3- Основні характеристики тепловізора

\begin{tabular}{|c|c|}
\hline Характеристика & Значення \\
\hline Збільшення, крат. & не менше 7 \\
\hline Поле зору, град & не менше 11 \\
\hline Дальність бачення цілі вночі, м & \\
\hline $\begin{array}{l}\text { виявлення } \\
\text { розпізнання } \\
\text { ідентифікація }\end{array}$ & $\begin{array}{l}\text { не менше } 5000 \\
\text { не менше } 2300 \\
\text { не менше } 1500\end{array}$ \\
\hline
\end{tabular}

Балістичний калькулятор повинен розраховувати поправки в напрямок та приціл, що потрібні при стрільбі по цілях напівпрямою та прямою наводкою, 3 точністю до 0-00,5 в напрямок та до 0,5 поділки в приціл з часом обробки даних до 0,5 сек.

Враховуючи зазначене, можливості модернізованого прицілу повинні повною мірою забезпечувати виконання завдань за призначенням 100-мм протитанкової гармати MT-12, а саме: ураження танків, бронетранспортерів, самохідних-артилерійських установок та інших броньованих засобів противника;

стрільбу по бронековпаках, амбразурах, довгочасних вогневих спорудах;

знищення живої сили та вогневих засобів противника, що знаходяться поза укриттям або в легких укриттях.

Основні тактико-технічні характеристики 100-мм гармати МТ-12 наведено в таблиці 4 [1]. 
Таблиця 4- Основні тактико-технічні характеристики 100-мм протитанкової гармати МТ-12

\begin{tabular}{|l|c|}
\hline \multicolumn{1}{|c|}{ Характеристика } & Значення \\
\hline Калібр, мм & 100 \\
\hline Найбільша дальність стрільби, м: & 8200 \\
ОФ снарядом & 5955 \\
кумулятивно-осколковим снарядом & 3000 \\
бронебійним підкаліберним снарядом & \\
\hline Дальність прямого пострілу, м & \\
а) при висоті цілі 2,7 (2,3) м: & 2130 \\
бронебійним підкаліберним снарядом & 1150 \\
кумулятивно-осколковим снарядом & \\
б) при висоті цілі 2,0 м: & 1880 \\
бронебійним підкаліберним снарядом & 1020 \\
кумулятивно-осколковим снарядом & \\
\hline Висота лінії вогню, мм & 810 \\
\hline Кути наведення, град.: & \pm 27 \\
горизонтальної & \\
вертикальної & \\
\hline Найбільша швидкість транспортування, км/год & \\
\hline
\end{tabular}

Таким чином, завдання та можливості модернізованого прицілу повинні повною мірою забезпечувати виконання завдань за призначенням 100-мм гармати МТ-12 та Висновки

Завдання модернізації парку 100-мм протитанкових гармат МТ-12 3С України $\epsilon$ доцільним і дозволить підняти рівень бойової ефективності артилерійського протитанкового озброєння до рівня сучасних зразків відповідного сегменту артилерійського ОВТ розвинутих у воєнному відношенні держав.

3 метою підвищення ефективності відповідати наведеним кількісним та якісним характеристикам обладнання зі складу виробу.

\section{Список використаних джерел}

1. 100-мм противотанковая пушка МТ-12. Руководство службы. - М: Воениздат, 1980. $-320 \mathrm{c}$.

2. Можливості оборонно-промислового комплексу України в системі національної безпеки. Аналітична записка. URL: http://old2.niss.gov.ua/articles/251/

3. Артилерійський приціл нічний АПН6-40. URL: http://bookwu.net/book_artileriya_993 /30_5.3.-artilerijskij-pricil-nichnij-apn6-40

4. Тепловізор.

URL: https://uk.wikipedia.org/wiki/Тепловізор

5. Тепловизионный прицел - последняя виконання завдань за призначенням та забезпечення автономності протитанкових артилерійських підрозділів необхідно проводити оснащення додатковим обладнанням, а саме: комплексу засобів автоматизації та зв'язку [7], радару вимірювання дульної швидкості снарядів [8] і системи навігації та топогеодезичної прив'язки. разработка российских учёных. URL: https://topwar.ru/7728-teplovizionnyypricel-poslednyaya-razrabotka-rossiyskihuchenyh.html

6. Тепловизионный прицел. URL: http://www.pergam.ua/catalog/thermal_im agers/hunting_camera/guidir-ts445. html;

7. Вимоги до автоматизованої системи управління ракетних військ і артилерії Збройних Сил України (стосовно артилерії) (шифр - “Акація-артилерія"): звіт про НДР. - Суми: НЦБЗРВіА ВІРВіА СумДУ, 2006. 272 c. 


\begin{tabular}{lll}
\hline 8. Аналіз ефективності дооснащення & інституту Київського національного \\
артилерійських систем РлС для & університету імені Тараса Шевченка, - \\
визначення швидкості вильоту снаряда / & 2015. - Вип. 49. - C. 18-29. URL: \\
Ю. І. Бударецький, Ю.В. Щавінський // & http://nbuv.gov.ua/UJRN/Znpviknu_2015_4 \\
Збірник наукових праць Військового & 9 9.
\end{tabular}

\title{
Обоснование технических требований к прицелам противотанковых артиллерийских орудий
}

\author{
Алексей Лазня * 1 А; Николай Дорофеев ${ }^{2}$ в; Борис Мельник 3 в \\ * Corresponding author: ${ }^{1}$ начальник научно-исследовательской лаборатории, e-mail: 1980yanzal@gmail.com, ORCID: 0000-0003-3667-2418 \\ ${ }^{2}$ к.т.н., научный сотрудник научно-исследовательского отдела, e-mail: dorofeev83@meta.ua, ORCID: 0000-0001-8607-2483 \\ ${ }^{3}$ к.т.н., начальник научно-исследовательского отдела, e-mail: melnikboss1@gmail.com, ORCID: 0000-0002-5635-0099 \\ ${ }^{\text {А } Н а у ч н о-и с с л е д о в а т е л ь с к и и ̆ ~ ц е н т р ~ р а к е т н ы х ~ в о и ̆ с к ~ и ~ а р т и л л е р и и, ~ г . ~ С у м ы, ~ У к р а и н а ~}$

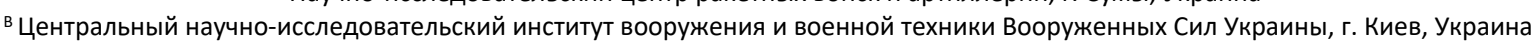

\begin{abstract}
Аннотация
Рассмотрены вопросы формирования технических требований к модернизированным прицелам противотанковых артиллерийских орудий, предложены варианты их приборного оснащения и требования к нему.

Эффективность применения противотанковых средств при ведении боевых действий зависит от их характеристик, среди которых - возможность распознавания и поражения целей в любое время года и время суток.

100-мм противотанковая пушка МТ-12 оборудована оптическим прицелом, который не в полной мере обеспечивает наведение ее на цель в условиях ограниченной видимости, а ночной прицел АПН-6-40 является конструктивно устаревшим и малоэффективным. Это заставляет вести активный поиск путей решения проблемы боевого применения данного типа образца ВВТ, одним из которых является модернизация противотанкового артиллерийского прицела, который заменит существующие и, в целом, повысит боевую эффективность противотанковой пушки.

Анализ аналогичного по типу вооружения наиболее развитых в военном отношении стран свидетельствует, что путь модернизации значительной части вооружения и военной техники является перспективным, кроме того, финансовые затраты на развитие образца ВВТ (модернизацию) могут быть уменьшены в несколько раз по сравнению с созданием нового образца ВВТ. Во многих странах модернизация рассматривается как один из основных путей технического обеспечения обороноспособности вооруженных сил. Так, например, США при принятии решения о необходимости разработки и производства новой системы оружия учитывают возможности модернизации оружия, находящегося в эксплуатации. Положительное решение принимается только в том случае, если все возможности модернизации исчерпаны или она нецелесообразна.
\end{abstract}

Ключевые слова: противотанковая артиллерийская пушка, модернизированный прицел, дополнительное оборудование.

\section{Justification of technical requirements for the sight anti-tank artillery}

\author{
Oleksiy Laznya * 1 A; Nickolay Dorofeev ${ }^{2}$ B; Boris Melnyk 3 B \\ * Corresponding author: ${ }^{1}$ Head of Research Laboratory, e-mail: 1980yanzal@gmail.com, ORCID: 0000-0003-3667-2418 \\ 2 Ph.D., Research Fellow, e-mail: dorofeev83@meta.ua, ORCID: 0000-0001-8607-2483 \\ ${ }^{3}$ Ph.D., Head of Research Department, e-mail: melnikboss1@gmail.com, ORCID: 0000-0002-5635-0099
}




\footnotetext{
A Research Center for Missile Forces and Artillery, Sumy, Ukraine

${ }^{B}$ Central Research Institute of weapons and military equipment of the Armed Forces of Ukraine, Kyiv, Ukraine
}

\begin{abstract}
The issues of the formation of technical requirements for the modernized sights of anti-tank artillery guns are considered, options for their instrumentation and requirements for it are proposed.

The effectiveness of the use of anti-tank weapons in the conduct of hostilities depends on their characteristics, among which is the possibility of recognizing and hitting targets at any time of the year and time of day.

The 100-mm MT-12 anti-tank cannon is equipped with an optical sight, which does not fully ensure it aiming at a target in conditions of limited visibility, and the APN-6-40-night sight is structurally outdated and ineffective. This forces an active search for ways to solve the problem of the combat use of this type of weapons and military equipment, one of which is the modernization of the anti-tank artillery sight, which will replace the existing ones and, in general, increase the combat effectiveness of the anti-tank cannon.

An analysis of similar weapons in the most militarily developed countries shows that the path of modernization of a significant part of weapons and military equipment is promising, in addition, the financial costs of developing a model of weapons and military equipment (modernization) can be reduced several times in comparison with the creation of a new model of weapons. In many countries, modernization is viewed as one of the main ways of providing technical support for the defense capability of the armed forces. For example, the United States, when deciding on the need to develop and produce a new weapon system, takes into account the possibilities of modernizing weapons in service. A positive decision is made only if all the possibilities of modernization have been exhausted or it is inexpedient.
\end{abstract}

Keywords: anti-tank artillery gun, upgraded sight, additional equipment.

\title{
References
}

1. 100-mm protivotankovaya pushka MT-12. Rukovodstvo sluzhby. Moscow: Voyenizdat, 1980. $320 \mathrm{~s}$.

2. Mozhlivostí oboronno-promislovogo kompleksu Ukrainy $v$ sistemí natsíonal'noy bezpeki. Analítichna zapiska. Available from: http://old2.niss.gov.ua/articles/251/

3. Artileríys'kiy pritsíl níchniy APN6-40. Available from:

http://bookwu.net/book_artileriya_993/30_5. 3.-artilerijskij-pricil-nichnij-apn6-40;

4. Teplovízor. Available from: https://uk.wikipedia.org/wiki/Teplovízor;

5. Teplovizionnyy pritsel - poslednyaya razrabotka rossiyskikh uchonykh. Available from: https://topwar.ru/7728-teplovizionnyy-pricelposlednyaya-razrabotka-rossiyskihuchenyh.html;
6. Teplovizionnyy pritsel. Available from: http://www.pergam.ua/catalog/thermal_imag ers/hunting_camera/guidir-ts445. html;

7. Vimogi do avtomatizovannoy sistemy upravleniya raketnymi víys'kí artilleriyey Zbroynykh Sil Ukraïni (shifr - «Akatsíyaartilleriya»): zvít pro NDR. Sumi: NTSBZRVíA VÍRVíA SumDU, 2006. $272 \mathrm{~s}$.

8. Analíz yefektivnosti doosnashcheniya artileríys'kikh sistem RLS dlya opredeleniya skorosti vil'otu snaryada / YU.Í. Budarets'kiy, YU.V. Shchavíns'kiy // Zbírnik naukovikh prats' Víys'kovogo ínstitutu Kiïvs'kogo natsíonal'nogo uníversitetu ímení Tarasa Shevchenka, 2015. Vip. 49. s. 18-29. Available from: http://nbuv.gov.ua/UJRN/Znpviknu_ 2015_49_5. 